\title{
The Efficiency of the Energy Saving Stoves in Amboseli Ecosystem-Analysis of Time, Energy and Carbon Emissions Savings
}

\author{
David Owino Manoa*, Tim Oloo, Simon Kasaine \\ Born Free Foundation, Nairobi, Kenya \\ Email: ^davidmanoa@me.com
}

How to cite this paper: Manoa, D.O., Oloo, T. and Kasaine, S. (2017) The Efficiency of the Energy Saving Stoves in Amboseli Ecosystem-Analysis of Time, Energy and Carbon Emissions Savings. Open Journal of Energy Efficiency, 6, 87-96. https://doi.org/10.4236/ojee.2017.63007

Received: June 23, 2017

Accepted: August 26, 2017

Published: August 29, 2017

Copyright ( 92017 by authors and Scientific Research Publishing Inc. This work is licensed under the Creative Commons Attribution International License (CC BY 4.0).

http://creativecommons.org/licenses/by/4.0/

\begin{abstract}
It is estimated that more than 2.5 billion people worldwide use biomass for cooking. Burning biomass is one of the major contributors to carbon dioxide $\left(\mathrm{CO}_{2}\right)$ emission-a principle gas in global warming and climate change. One way of cutting down the $\mathrm{CO}_{2}$ emissions is adaptation of efficient and clean energy technologies. This study examined the efficiency of the energy saving stoves in Amboseli ecosystem by comparing the cooking time, energy use, wood fuel and carbon emissions to the traditional three stone open fire set ups. The result indicates a statistical difference in the time spent cooking on energy stoves and three stone open fire $(t=5.3055 ; n=60 ; p=0.00117)$. Energy saving stoves saved $12.7 \%-33.3 \%$ of wood fuel compared to the traditional three stones set ups. Water boiling tests to determine the energy savings, revealed that energy saving stoves saved between $25.74 \%$ and $26.16 \%$ energy/joule per session in-house and outdoor settings respectively. Based on the two meals prepared per day by each household, the total Carbon Emission Savings for the 1000 local beneficiaries of energy saving stoves varied from $102,200 \mathrm{~kg} \mathrm{CO}_{2}$ (indoor cooking) to $357,700 \mathrm{~kg} \mathrm{CO}_{2}$ (outdoor cooking) per year. It is therefore concluded that energy saving stoves saves time, fuel wood and energy, and reduces carbon emissions. The study findings refute the claims that open fire when carefully operated can be fuel efficient and clean burning to rival energy saving stoves. To improve the performance of the energy saving stoves, it is recommended that a design modification be done to include a chimney to emit excess smoke during indoor cooking; and the stove should be fixed to the floor with mortar to minimise heat loss and breakages.
\end{abstract}

\section{Keywords}

Energy-Saving Stoves, Time, Carbon Dioxide, Fuel Wood, Efficiency, Amboseli 


\section{Introduction}

More than 2.5 billion people worldwide use biomass such as wood and dung for cooking. This number is projected to increase to 2.7 by 2030 due to a growing human population [1]. The over reliance on biomass energy is one of the major causes of environmental degradation and a contributor to the greenhouse gases (GHG) emissions, such as Carbon dioxide $\left(\mathrm{CO}_{2}\right)$. There have been efforts to develop more efficient and clean energy technologies around the world to reduce the $\mathrm{CO}_{2}$ emissions and mitigate climate change. This is quite important to the field of conservation because climate change has already affected the global biodiversity by altering reproductive cycles, growing seasons, and ways in which species interact in terms of predation, pollination, competition and disease [2]. Consequently, simple technologies such as energy saving cooking stoves have been developed to help reduce the deforestation, minimise wildlife habitats loss and smoke related illness. Although the energy saving stoves have been documented to reduce the amount of fuel consumptions in households, most are designed to make use of solid biomass as fuel, hence depending on forest resources for their operations. In addition, there are numerous designs of the energy saving stoves and that calls for an evaluation to document their performance and recommend which design to use when and where. Regardless of the design, energy saving stoves must be of higher energy efficiency compared to the conventional cooking methods such the three stones set up to justify their implementation.

Born Free Foundation (BFF) in collaboration with the Eden Wildlife Trust (EWT) initiated the ongoing energy saving stoves project in Amboseli ecosystem in the year 2015 (Figure 1). The goal of the project is to save the wildlife dispersal areas around Amboseli National Park. It was predicted that the rate of wood fuel fetching and quantity of consumption in households would reduce by $50 \%$ with the implementation of energy saving stoves. Although, there has been about $30 \%$ reduction in fuel wood consumption and the rate of fetching minimised to
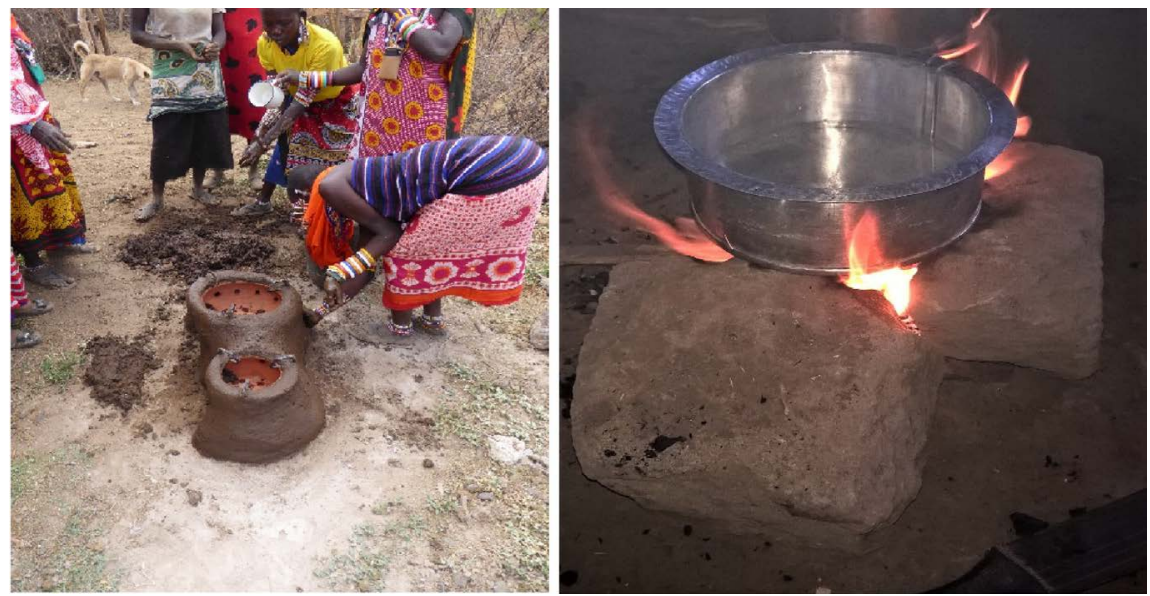

Figure 1. Left: Amboseli women group installing a model energy saving stoves during the training session, and Right: three stone traditional open fire set up. 
only once a week compared to daily, three key questions remain unanswered:

1) Is there any significant difference in the time spend per cooking session with three stone traditional open fire and the energy saving jikos?

2) What is the energy and the quantity of firewood used per cooking session using the energy saving stoves and on three stone traditional open fire?

3) What are the total carbon emissions saving when using the energy saving stoves per cooking session?

To answer these questions, a designed experiment was conducted using a participatory approach in randomly selected households (HH) in Amboseli. This study tested the hypothesis by some scholars (see for example [3] on: Design Principles for Wood Burning Cook Stoves) that:

“... open fires are often used wastefully, carefully operated open fires can be fuel efficient and clean burning... in many situations, cooks are not overly concerned with fuel use... when fuel is plentiful three-stone fires can use an excessive amount of wood to cook a small amount of food. But where fuel is scarce, open fires can be carefully controlled so that fuel efficiency rivals many first generation improved cook stoves."

\section{Material and Methods}

\subsection{Experimental Procedures}

Thirty households $(\mathrm{HH})$ were randomly selected from a list of 1000 beneficiaries of energy saving stoves. Each selected household $(\mathrm{HH})$ was provided with two cooking pots (same size-diameter $16 \mathrm{~cm}$, depth-18 cm, material-aluminium and thickness-3 mm); measured quantities (kgs) of dry firewood (Hook-thorn/ Waita-bit thorn-Acacia mellifera); 1 kilogrammes of white rice, 1 kilogrammes of dry yellow beans; $100 \mathrm{ml}$ of paraffin to kick start the fire; 1 litres of milk; $10 \mathrm{ml}$ of tea granules; and 20 litres of water. For every energy saving stove set up, a three stone traditional open fire was installed using three bricks of same thickness $(15.5 \mathrm{~cm})$ and height $(23 \mathrm{~cm})$ from the floor.

Based on the basic principle of impurities raises the boiling point of liquids, the water for use in the entire experiment period was fetched from one source-a borehole. This was to ensure that there was minimal variation in the water impurity among the $\mathrm{HH}$. Five women were selected to participate in the cooking experiments daily for 6 consecutive days in May, 2017.

\subsubsection{Energy Saving Stoves Used}

The energy saving stoves used in this study are made of clay soil. They are cylindrical shaped with an average diameter of about $30 \mathrm{~cm}$, height of $23 \mathrm{~cm}$, wall thickness of $4 \mathrm{~cm}$, and a door opening measuring $16 \mathrm{~cm} \times 12 \mathrm{~cm}$. The stoves are fixed on the floor with clay soil.

\subsubsection{Food Cooking and Water Boiling Tests}

A $0.5 \mathrm{kgs}$ of yellow beans were put into two different cooking pots, 1 litre of water was added to each pot, and the initial temperature of the mixture taken using 
Hanna HI98501 digital thermometer. For the white rice cooking, the mixture consisted of $0.5 \mathrm{kgs}$ rice and 1 litre of water. Pieces of fire wood (consisting of mixture 6 inch pieces, 1 feet and 2 feet long) were set up in both the energy saving stoves and the three stone open fire combustion chambers. The fire was ignited using $50 \mathrm{ml}$ of paraffin, and after 30 seconds the cooking pots were put on energy saving stove and another on the three stone set up. A digital stop watch was used to record the time taken to cook the foods. Rice was considered to have cooked when all the water had dried while the yellow beans crushed easily between the index and the thumb fingers when cooked. To prepare white tea, we used a mixture of 1/2 litre of milk, 1 litres of water and $5 \mathrm{ml}$ of tea granules. The mixture was heated until it boiled and rose close to the brim of the cooking pot. Another experiment was conducted using 1 litre of water to determine the time taken to reach the boiling point and the change in temperatures. For all the experiments, the unburned wood fuel was removed, the flame extinguished, loose carbon removed and weighted to determine the quantities of wood fuel used for cooking and boiling water. These procedures were repeated for indoor and outdoor set up for both energy saving stoves and the three stone fire set up in 30 selected households. All the experiments were conducted without cover lids on the cooking pots.

\subsubsection{Wood Fuel for the Experiment}

The dried Hook-thorn acacia was used for the cooking tests. Hook-thorn acacia is a low shrub that grows to $2-8 \mathrm{~m}$ height. It is commonly found in dry bushland up to an altitude of $1800 \mathrm{~m}$ above the sea level [4]. The dry-hook thorn acacia used in this experiment was naturally occurring dead wood felled by elephants within the study area. The study area is semi-arid with annual average temperature of $18.9^{\circ} \mathrm{C}$ [5] and the firewood gathered had been lying outdoor for more than three months with no rains. 10 days prior to the experiments, the collected pieces of firewood were stored inside a Maasai hut close to the cooking area for further drying. This ensured that the firewood used was completely dry with minimum moisture content.

\subsection{Estimation of Varibles}

\subsubsection{Carbon Emission Calculation}

To determine the performance of the energy saving stoves, fuel wood saved (WFS) from cooking/boiling water for every $\mathrm{HH}$; default fraction of non-renewable biomass (fNRB) by United Nation Frame Convention on Climate Change (UNFCCC) for Kenya; Net Calorific Value; and default emission factor per unity of energy (EF) were used to calculate the Carbon Emissions Saving (CES) as recommended by [6].

$$
\mathrm{CES}=\mathrm{WFS} \times \mathrm{fNRB} \times \mathrm{NCV} \times \mathrm{EF}
$$

Variables description:

fNRB - is the fraction of woody biomass saved by a project activity that can be established as non-renewable biomass, has a direct impact on GHGs emission reductions therefore its assessment is of significant importance. $\mathrm{NRB}$ are calcu- 
lated by the project developer to correspondent to the project's geographical area, in order for the woody biomass project be certified for carbon credits. The default $\mathrm{ANRB}$ value have already been approved by the Clean Development Mechanism Executive Board (CDM EB) and accepted by the designated national authority (DNA). Kenya default value is $92 \%$;

NCV-Net calorific value calculated value of the specific energy of combustion for unit mass of a fuel burned in oxygen at constant pressure under such conditions that all the water of the reaction products remain as water vapour and the other products being as for the gross calorific value, all at the reference. The NCV of oven-dry wood of different species varies within a very narrow interval, from 18.5 to $19 \mathrm{MJ}$ per $\mathrm{kg}$. This study used the NCV of Black thorn/ Wait-abit thorn (Acacia mellifera) of $19.188 \mathrm{KJ} / \mathrm{kg}$ [7].

$\mathrm{EF}$-the carbon emission factor for the biomass fuel $=112 \mathrm{~g}$ of $\mathrm{CO}_{2}$ per MJ of fuel wood (IPCC, 2006b).

\subsubsection{Time Saving Calculation}

The time saved (TS) using the energy saving stoves was calculated for food and water of the same quantity as:

$$
\mathrm{TS}=\mathrm{TCF}-\mathrm{TCE}
$$

where:

TCF = time spend cooking with three stone traditional open fire;

$\mathrm{TCE}=$ time spend cooking with energy saving stoves.

\subsubsection{Energy Saved Calculation}

The energy saved was calculated as the difference between energy released while cooking on three stone traditional stone and the energy saving stoves. The initial and final boiling point of water was determined using Hanna HI98501 digital thermometer.

$$
\begin{aligned}
\text { Energy released }(\mathrm{J} / \mathrm{g} \text { of fuel }) & =\frac{\text { Energy transferred to water }(\mathrm{J})}{\text { Mass of fuel burned }(\mathrm{g})} \\
\text { ER } & =\frac{\mathrm{ET}}{\mathrm{M}}
\end{aligned}
$$

To determine the energy transferred, the following formula was used:

Energy transferred (joules, $\mathrm{J}$ ) $=$ mass of water heated (grams, $\mathrm{g}$ ) $\times$ the specific heat capacity of water $\left(4.2 \mathrm{~J} / \mathrm{g} \cdot{ }^{\circ} \mathrm{C}\right) \times$ change in temperature rise $\left({ }^{\circ} \mathrm{C}\right)$.

$$
\mathrm{ET}=\mathrm{MW} \times 4.2 \times \Delta \mathrm{T}
$$

\section{Results and Discussions}

\subsection{Time Saved}

In all the cooking experiments, the energy saving stoves took less time to cook food and boil 1 litre of water. Less time was spent cooking yellow beans on energy saving stoves outside the huts ( 7.3 minutes compared to the inside the hut cooking set up (9.96 minutes). Preparing white tea had the maximum mean time savings (3.63 minutes) while cooking rice inside the huts had the least mean 
time saving (0.28 minutes). Cooking outside the hut in general resulted to more time savings during the experiments (Table 1). These findings are similar to those of [8] which revealed that energy saving stoves saved time (an average of 28 minutes) compared to open fires when baking Injera (a white leavened Ethiopian bread made from teff flour) in Ethiopia.

However, this study did not record high time savings per cooking sessions compared to [1] and [8]. In a study conducted by [1], the energy saving stoves dubbed "Save 80 " reduced the time taken to cook on open fire by $80 \%$. The differences in time savings between this study and other studies can be attributed to the different designs of the energy saving stoves and the different foods cooked. Unlike the Save80 and the Chigr Fetch multipurpose stoves, the energy saving stoves used in this experiment were very basic in design, with clay liners either covered with mud or exposed. This could have allowed more heat to escape from the stoves and hence saving less time as compared to other stove models. Secondly, the size of the energy saving stoves used in this experiment were smaller-30 $\mathrm{cm}$ in diameter and $23 \mathrm{~cm}$ high (Figure 2) compared to the Save80 and

Table 1. Time taken to cook different foods and boil water with energy and three stone traditional open fire set ups.

\begin{tabular}{|c|c|c|c|c|c|c|}
\hline \multirow{2}{*}{$\begin{array}{l}\text { Experimental substance - } \\
\quad \text { (Food \& water) }\end{array}$} & \multicolumn{3}{|c|}{$\begin{array}{c}\text { Inside the huts set up experiment } \\
\text { time taken (Min) }\end{array}$} & \multicolumn{3}{|c|}{$\begin{array}{c}\text { Outside the huts experimental set up } \\
\text { time taken (Min) }\end{array}$} \\
\hline & $\begin{array}{l}\text { Energy } \\
\text { saving } \\
\text { stoves }\end{array}$ & $\begin{array}{l}\text { Three stone } \\
\text { traditional } \\
\text { open fire }\end{array}$ & $\begin{array}{l}\text { Time Saved } \\
\text { (Minutes) }\end{array}$ & $\begin{array}{l}\text { Energy } \\
\text { saving } \\
\text { stoves }\end{array}$ & $\begin{array}{l}\text { Three stone } \\
\text { traditional } \\
\text { open fire }\end{array}$ & $\begin{array}{l}\text { Time Saved } \\
\text { (Minutes) }\end{array}$ \\
\hline $\begin{array}{l}\text { White rice } \\
(0.5 \mathrm{~kg} \cdot \mathrm{s})\end{array}$ & 11.44 & 11.72 & $0.28 \mathrm{~min}$ & 14.37 & 15.73 & $1.36 \mathrm{~min}$ \\
\hline Water (1 Litre) & 9.96 & 11.35 & $1.39 \mathrm{~min}$ & 5.58 & 7.3 & $1.72 \mathrm{~min}$ \\
\hline Yellow beans ( $0.5 \mathrm{~kg} \cdot \mathrm{s})$ & 39.71 & 42.10 & $2.39 \mathrm{~min}$ & 35.87 & 38.49 & $2.62 \mathrm{~min}$ \\
\hline $\begin{array}{l}\text { White tea ( } 1 \text { litre water }+ \\
0.5 \text { litre milk }+5 \mathrm{ml} \text { tea } \\
\text { leaves) }\end{array}$ & 5.67 & 7.3 & $1.63 \mathrm{~min}$ & 6.01 & 9.64 & $3.63 \mathrm{~min}$ \\
\hline
\end{tabular}

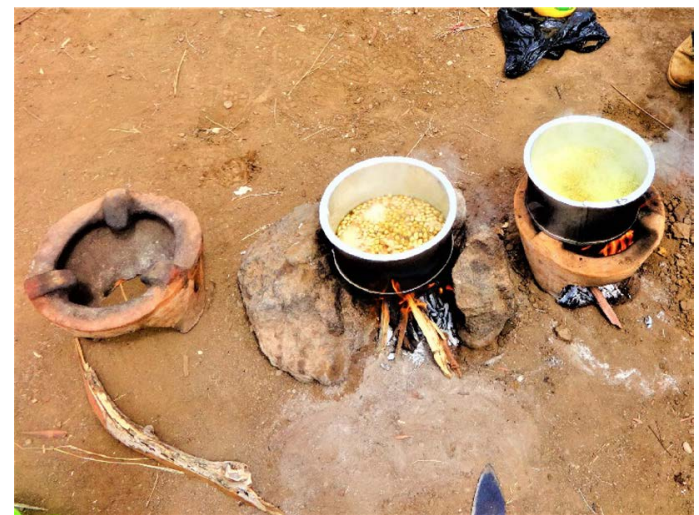

Figure 2. Left energy saving stoves liner, Middletraditional open fire, and Right-energy saving stoves with fire. 
Chigr Fetch multipurpose stoves.

A paired student-t-test showed a significant difference in time spent cooking on energy saving stove and the open fire set up $(\mathrm{t}=5.3055 ; \mathrm{n}=60 ; \mathrm{P}=0.00117)$. The time saved per household can be used by the families for other domestic chores. A study conducted by [9] found out that the "cost" of gathering firewood in India was between 200 and 300 person-days per family per year-a fulltime job for one person. [9] further assert that in sub-Saharan Africa people travel on foot or animals drawn cart as far as $50 \mathrm{~km}$ for firewood, and where firewood is purchased it costs about $25 \%$ of the family's income.

\subsection{Wood Fuel Saved}

The energy saving stoves consumed less wood fuel than the three stone traditional open fire wood set up. Cooking outside the huts saved more wood fuel than cooking inside the huts (Table 2). This could be as result of the wind that fuelled more combustion in three stone traditional set than in energy saving stoves. The energy saving stoves had only one main entry, that allowed wind to enter the combustion chamber as opposed to the three stone set up that had three different entrances. The flow of wind from three different direction could have speed the combustion process at the same time blowing the fire away from the cooking pots in the three stone set ups. Cooking per sessions saved wood fuel between $12.73 \%$ and $33.33 \%$. When combined, cooking tests outside the huts resulted to a wood fuel saving of $16.44 \%$ compared to the inside set up of $15.52 \%$. [9] asserts that "even a $10 \%$ or $20 \%$ reduction in the use of firewood is a significant results".

Children contribute to family labour such as firewood fetching where labour saving technologies such as energy saving stoves are not in place [10]. As such, it can be argued that reduction in wood fuel consumptions and time taken for cooking can not only gives women time to do other chores, but also give the children ample time to play and study.

All the 60 cooking experiments saved $31.96 \%$ of the wood fuel. A paired student $\mathrm{t}$-test found a significant difference in the quantity of wood fuel saved by

Table 2. Wood fuel savings for cooking inside and outside the huts.

\begin{tabular}{|c|c|c|c|c|c|c|}
\hline \multirow[b]{2}{*}{$\begin{array}{l}\text { Experimental substance } \\
\text { (Food \& water) }\end{array}$} & \multicolumn{3}{|c|}{ Inside the huts experiment } & \multicolumn{3}{|c|}{ Outside the huts experiment } \\
\hline & $\begin{array}{l}\text { Energy saving } \\
\text { stoves wood in } \\
\mathrm{kg} \cdot \mathrm{s} \text { used }\end{array}$ & $\begin{array}{c}\text { Three stone } \\
\text { traditional open } \\
\text { fire wood in kg.s } \\
\text { used }\end{array}$ & $\begin{array}{l}\text { Wood Fuel } \\
\text { Saved } \\
\text { (WFS) }\end{array}$ & $\begin{array}{l}\text { Energy saving } \\
\text { stoves wood in } \\
\mathrm{kg} \cdot \mathrm{s} \text { used }\end{array}$ & $\begin{array}{l}\text { Three stone } \\
\text { traditional open fire } \\
\text { wood fire in } \mathrm{kg} \cdot \mathrm{s} \\
\text { used }\end{array}$ & $\begin{array}{c}\text { Wood Fuel } \\
\text { Saved } \\
\text { (WFS) }\end{array}$ \\
\hline White rice $(0.5 \mathrm{~kg} \cdot \mathrm{s})$ & 0.48 & 0.55 & $0.07 \mathrm{~kg} \cdot \mathrm{s}$ & 0.54 & 0.68 & $0.14 \mathrm{~kg} \cdot \mathrm{s}$ \\
\hline Water (1 Litre) & 0.40 & 0.54 & $0.14 \mathrm{~kg} \cdot \mathrm{s}$ & 0.47 & 0.64 & $0.17 \mathrm{~kg} \cdot \mathrm{s}$ \\
\hline Yellow beans $(0.5 \mathrm{~kg} \cdot \mathrm{s})$ & 2.3 & 2.41 & $0.11 \mathrm{~kg} \cdot \mathrm{s}$ & 2.4 & 2.55 & $0.15 \mathrm{~kg} \cdot \mathrm{s}$ \\
\hline $\begin{array}{c}\text { White tea ( } 1 \text { litre water }+ \\
0.5 \text { litre milk }+5 \mathrm{ml} \text { tea } \\
\text { leaves) }\end{array}$ & 0.43 & 0.58 & $0.15 \mathrm{~kg} \cdot \mathrm{s}$ & 0.5 & 0.75 & $0.25 \mathrm{~kg} \cdot \mathrm{s}$ \\
\hline
\end{tabular}


energy saving stoves and three stone traditional open fire $(t=8.1043 ; n=60 ; p<$ 0.05). [11] argues that even a slight wood fuel savings (as in this study) can be impactful in areas with scarcity of fuel wood such as Amboseli region. This study findings are analogous with the [11] study in Tanzania and Uganda, where field test of energy saving jikos (UgaStove and StoveTec) had a fuel saving of $38 \%$. Another controlled cooking experiments conducted by World Food Programme [12] in 2013 in Kakuma refugee camp in Kenya showed that energy saving stoves saved between $30 \%-40 \%$ of the wood fuel.

\subsection{Carbon Emission Savings}

The carbon emission savings (CES) per cooking session with the energy saving stoves varied from $0.14 \mathrm{~kg} \mathrm{CO}$ to $0.49 \mathrm{~kg} \mathrm{CO}$. The average CES for the three cooked foods and water boiling was slightly higher outside huts-0.35 $\mathrm{kg} \mathrm{\textrm {CO } _ { 2 }}$ compared to inside the hut cooking set up-0.24 $\mathrm{kg} \mathrm{CO}_{2}$ (Table 3). The energy saving stove in this study showed a lower CES compared to other studies. For instance a study conducted to cook Injra in Ethiopia indicated that Mirte and Gonziye energy saving stoves had a CES of 2.298 ton $\mathrm{CO}_{2}$ per stove [13] First, the differences can be attributed to the fact that three-stone method is quite vigorous against different stove setups, while energy savings stoves needs a specific setup to achieve the highest efficiency values [14]; secondly the design of the two energy saving stoves are different and the fire wood used are different. [15] emphasises that the need for the design of the energy saving stove to suit the local situations to avoid the problem of households requiring for example to split the firewood into small pieces, a task which consume time and require tools. Based on the average of two meals prepared per day by each household, the total CES for the 1000 local beneficiaries of energy saving stoves varied from 102,200 kg $\mathrm{CO}_{2}$ to $357,700 \mathrm{~kg} \mathrm{CO}$ per year. A study conducted by [16] in Kenya, indicated that that the daily carbon emissions from improved ceramic woodstoves (5905 \pm $1553 \mathrm{~g}$ of $\mathrm{C})$ were lower than traditional open fire (5990 $\pm 1843 \mathrm{~g}$ of C). However, these results were not statistically significant, just like in this study.

Table 3. Carbon emission savings and wood fuel burning rates.

\begin{tabular}{|c|c|c|c|c|c|c|}
\hline \multirow[b]{2}{*}{$\begin{array}{l}\text { Experimental substance } \\
\text { (Food \& water) }\end{array}$} & \multicolumn{3}{|c|}{ Inside the huts experiment } & \multicolumn{3}{|c|}{ Outside the huts experiment } \\
\hline & $\begin{array}{l}\text { Energy saving } \\
\text { stoves wood } \\
\text { burning rate } \\
(\mathrm{g} / \mathrm{min})\end{array}$ & $\begin{array}{l}\text { Three stone } \\
\text { traditional } \\
\text { open fire wood } \\
\text { burning rate } \\
\text { (g/min) }\end{array}$ & $\begin{array}{c}\text { Carbon Emission } \\
\text { Saving/ } \\
\text { stove/cooking } \\
\text { session } \\
\left(\mathrm{kg} \cdot \mathrm{COO}_{2}\right)\end{array}$ & $\begin{array}{l}\text { Energy saving } \\
\text { stoves wood } \\
\text { burning rate } \\
(\mathrm{g} / \mathrm{min})\end{array}$ & $\begin{array}{c}\text { Energy saving } \\
\text { stoves wood } \\
\text { burning rate } \\
(\mathrm{g} / \mathrm{min})\end{array}$ & $\begin{array}{c}\text { Carbon Emission } \\
\text { Saving/ } \\
\text { stove/cooking } \\
\text { session }\left(\mathrm{kg} \cdot \mathrm{CO}_{2}\right)\end{array}$ \\
\hline White rice $(0.5 \mathrm{~kg} \cdot \mathrm{s})$ & $41.96 \mathrm{~g} / \mathrm{min}$ & $46.93 \mathrm{~g} / \mathrm{min}$ & $0.14 \mathrm{~kg} \mathrm{CO}$ & $37.58 \mathrm{~g} / \mathrm{min}$ & $43.23 \mathrm{~g} / \mathrm{min}$ & $0.28 \mathrm{~kg} \mathrm{CO}$ \\
\hline Water (1 Litre) & $40.18 \mathrm{~g} / \mathrm{min}$ & $47.56 \mathrm{~g} / \mathrm{min}$ & $0.28 \mathrm{~kg} \mathrm{CO} 2$ & $84.23 \mathrm{~g} / \mathrm{min}$ & $87.67 \mathrm{~g} / \mathrm{min}$ & $0.34 \mathrm{~kg} \mathrm{CO} 2$ \\
\hline Yellow beans $(0.5 \mathrm{~kg} \cdot \mathrm{s})$ & $57.92 \mathrm{~g} / \mathrm{min}$ & $57.25 \mathrm{~g} / \mathrm{min}$ & $0.22 \mathrm{~kg} \mathrm{CO} 2$ & $66.90 \mathrm{~g} / \mathrm{min}$ & $66.25 \mathrm{~g} / \mathrm{min}$ & $0.30 \mathrm{~kg} \mathrm{CO} 2$ \\
\hline $\begin{array}{c}\text { White tea ( } 1 \text { litre } \\
\text { water }+0.5 \text { litre } \\
\text { milk }+5 \mathrm{ml} \text { tea leaves })\end{array}$ & $75.84 \mathrm{~g} / \mathrm{min}$ & $79.45 \mathrm{~g} / \mathrm{min}$ & $0.30 \mathrm{~kg} \mathrm{CO} 2$ & $83.20 \mathrm{~g} / \mathrm{min}$ & $77.80 \mathrm{~g} / \mathrm{min}$ & $0.49 \mathrm{~kg} \mathrm{CO} 2$ \\
\hline
\end{tabular}


Table 4. Energy saved during the boiling of water experiment.

\begin{tabular}{cccccc}
\hline \multicolumn{4}{c}{ Inside the huts experiments-Water Boiling } & Outside the huts experiments-Water Boiling \\
\hline $\begin{array}{c}\text { Energy saving } \\
\text { stoves-energy } \\
\text { released } \\
\text { in J/g) }\end{array}$ & $\begin{array}{c}\text { Three stone } \\
\text { traditional } \\
\text { open } \\
\text { fire-energy } \\
\text { released in J/g }\end{array}$ & $\begin{array}{c}\text { Energy } \\
\text { Saved } \\
(\mathrm{J} / \mathrm{g})\end{array}$ & $\begin{array}{c}\text { Energy saving } \\
\text { stoves energy } \\
\text { released } \\
\text { in J/g }\end{array}$ & $\begin{array}{c}\text { Three stone } \\
\text { traditional } \\
\text { open } \\
\text { fire-energy } \\
\text { released in J/g }\end{array}$ & $\begin{array}{c}\text { Energy } \\
\text { Saved } \\
(\mathrm{J} / \mathrm{g})\end{array}$ \\
744.24 & 552.69 & 191.55 & 591.75 & 436.93 & 154.82 \\
\hline
\end{tabular}

\subsection{Energy Saved}

The energy savings tests entailed boiling water both in the Maasai huts and outside the huts. Boiling water inside saved more energy (191.55 J/g) compared to outside set up $(154.82 \mathrm{~J} / \mathrm{g})$. The amount of energy released per gram of wood was higher for the energy saving stoves than in three stone traditional fire set ups (Table 4). A study conducted by [14] to test nine improved cooking stoves and five three stone fire set ups showed a total energy savings of $24.3 \%$. In this study, the energy saved ranged from $25.74 \%$ to $26.16 \%$ per water boiling session. The findings supports the [17] assertion that "reducing the amount of energy the world wastes is the first and best step toward fighting global warming... that almost one-half of the necessary climate mitigation will need to come from improved energy efficiency".

\section{Conclusion and Recommendations}

This study has demonstrated that simple energy saving stoves designs reduces the time used for cooking, saves energy and wood fuel used per session and reduces carbon emissions. These findings are essential to women in reducing the labour for fetching fire wood, to wildlife for regeneration of the shrubs and trees that forms their habitats, and in cutting down household's carbon emissions. The study findings refute the theory that, "open fire when carefully operated can be fuel efficient and clean burning to rivals many first generation improved cook stoves". However, the design of the energy saving stove requires a modification to minimise the amount of smoke generated during cooking. It was observed that smoke emission by energy saving stoves was irritating to the eyes and nose just like the three stone set up. The energy saving stove need to be re-designed to include a chimney that discharges the smoke from inside the huts to minimise the chance of the beneficiaries contracting respiratory related diseases. In addition, the energy saving stove should to be fixed on the floor with a mixture of soil and mortar. This will help to hold the stoves intact and prevent damages to the stoves. The amount of heat lost through convention method can equally be minimised by designing the stove in such a way that the cooking pots are placed inside, half way down the inner casing of the stoves.

\section{Acknowledgements}

We acknowledge the Born Free Foundation and Eden Wildlife Trust for facili- 
tating data collection and analysis. We also recognize the thirty households in Amboseli Ecosystem who dedicated their valuable time to the study.

\section{References}

[1] Adria, O. and Bethge, J. (2013) What Users Can Save with Energy-Efficient Cooking Stoves and Ovens. Wuppertal Institute for Climate, Environment and Energy.

[2] OECD/IEA (2006) Energy for Cooking in Developing Countries. https://www.iea.org/publications/freepublications/publication/cooking.pdf

[3] Bryden, M., Still, D., Scott, P., Hoffa, G., Ogle, D., Bailis, R. and Goyer, K. Design Principles for Wood Burning Cook Stoves. http://www.bioenergylists.org/stovesdoc/Pcia/Design\%20Principles\%20for\%20Woo d\%20Burning\%20Cookstoves.pdf

[4] Dharani, N. (2002) Field Guide to Common Trees \& Shrubs of East Africa. Struik Publishers, Cape Town.

[5] GoK (2009) Kajiado District Environment Action Plan 2009-2013.

[6] Intergovernmental Panel on Climate Change (IPCC) (2006) IPCC Guidelines for National Greenhouse Gas Inventories, Volume 4.4, Forest Land.

[7] Khider, T.O. and Elsaki, O.T. (2012) Heat Value of Four Hardwood Species from Sudan. Journal of Forest Products and Industries, 1, 5-9.

[8] Girma, W. (2015) Stove Test Results. Report on Controlled Cooking Test (CCT) \& Water Boiling Test (WBT) on: Chigr Fetch Multipurpose Stove. GIZ.

[9] Volunteers in Technical Assistance (1980) WOOD CONSERVING COOK STOVES. A Design Guide. Volunteers in Technical Assistance, Maryland.

[10] IFAD (2006) Reducing Vulnerability of the Girl Child in Poor Rural Areas Activities of the International Fund for Agricultural Development. UNICEF Innocenti Research Centre Florence, Italy.

[11] Adkins, E., Tyler, E., Wang, J., Siriri, D. and Modi, V. (2010) Field Testing and Survey Evaluation of Household Biomass Cookstoves in Rural Sub-Saharan Africa. Energy for Sustainable Development, No. 14, 172-185.

[12] WFP (2013) WFP Safe Project in Kenya. Controlled Cooking Test Report. World Food Programme.

[13] Biratu, A.A. (2016) The Implication of Wood-Burning Stove Efficiency for Environment, Health and $\mathrm{CO}_{2}$ Emissions in the Jogo-Gudedo Watershed, Ethiopia. Academic Research Journal of Agricultural Science and Research, 4, 154-163.

[14] Dresen, E., DeVries, B., Herold, M., Verchot, L. and Müller, R. (2014) Fuelwood Savings and Carbon Emission Reductions by the Use of Improved Cooking Stoves in an Afromontane Forest, Ethiopia. Land, 3, 1137-1157. https://doi.org/10.3390/land3031137

[15] Jones, M. (1989) Energy Efficient Stoves in East Africa: An Assessment of the Kenya Ceramic Jiko Program. Report to USAID, No. 89-01. Processed, Washington DC.

[16] Bailis R., Ezzati, M. and Kammen, D.M. (2003) Greenhouse Gas Implications of Household Energy Technology in Kenya. Environmental Science \& Technology, 37, 2051-2059. https://doi.org/10.1021/es026058q

[17] United Nation Foundation (2013) Improving Energy Efficiency. http://www.unfoundation.org/what-we-do/issues/energy-and-climate/improving-e nergy-efficiency.html 
Submit or recommend next manuscript to SCIRP and we will provide best service for you:

Accepting pre-submission inquiries through Email, Facebook, LinkedIn, Twitter, etc. A wide selection of journals (inclusive of 9 subjects, more than 200 journals)

Providing 24-hour high-quality service

User-friendly online submission system

Fair and swift peer-review system

Efficient typesetting and proofreading procedure

Display of the result of downloads and visits, as well as the number of cited articles Maximum dissemination of your research work

Submit your manuscript at: http://papersubmission.scirp.org/

Or contact ojee@scirp.org 